\title{
Fire risk at the wildland-urban interface: a case study of a Galician county
}

\author{
M. L. Chas-Amil ${ }^{1}$, E. García-Martínez ${ }^{1}$ \& J. Touza ${ }^{2}$ \\ ${ }^{I}$ Department of Quantitative Economics, \\ University of Santiago de Compostela, Spain \\ ${ }^{2}$ Department of Applied Economics, University of Vigo, Spain
}

\begin{abstract}
In Galicia (Spain), wildfires are one of the main environmental problems, with an annual average of close to 8,600 forest fires between 1999 and 2008. Most of these fires are intentionally ignited. It is therefore crucial for fire prevention policies to assess human-started fires and their relationship with socioeconomic aspects. In this paper we focus on the spatial pattern of human presence in the territory as an important determinant on forest fires ignitions. We identify, classified and map wildland-urban interface (WUI) and assess fire risk by types of WUI in a Galician county with one of the highest incidence of forest fires during the studied period (1999-2008). Following Lampin-Maillet et al. (Mapping wildland-urban interfaces at large scales integrating housing density and vegetation aggregation for fire prevention in the South of France. Journal of Environmental Management 2010) approach, and based on a combination of a map of buildings, obtained from the National Topographic Base, and the SIOSE land-cover map (Information system of land use cover in Spain) we distinguished among 12 types of interfaces. Our results show a significant relationship between the different types of WUI and the spatial patterns of wildfire ignition points. The highest density of fire ignition points was found in non-forest WUI with either dispersed or very dense clustered buildings.

Keywords: wildland-urban interface, forest fires risk, spatial analysis, Galicia.
\end{abstract}

\section{Introduction}

In Spain, wildfires are a recurrent phenomenon, with an annual average of 15,000 forest fires and 173,000 ha burned between 1980 and 2010 [3]. A 
significant proportion of these fires, and in particular those intentionally ignited, occurred in the region of Galicia, northwest of Spain [4]. Thus, during the period 1999-2008 an annual average of close to 8,600 forest fires burned about 40,000 ha in Galicia. Most fires are human-caused (99\%), mainly associated with intentional behavior $(80 \%)$, however only a limited number of research has specifically evaluated how the human presence in this territory increase the risk of fire ignition [5]. This contrast with the increasing literature on empirical assessments of the influence of socioeconomic aspects on forest fire risks, using variables such as population density, land cover changes associated to agriculture abandonment, distance to road networks or density of human settlements (e.g. [6-10]).

Wildland-urban interface (WUI), i.e. those areas where human infrastructure meets or intermingles with undeveloped wildland vegetation [11] are of particular concern in forest fire risk management. This is because WUI is often related with an increased danger of forest fire and a significant vulnerability to fire events. The presence of urbanized areas in contact with forest areas increases the likelihood of a fire starting as a consequence of human activities (e.g. [1216]. In addition, the presence of population living close to forestlands increases the vulnerability of these areas in terms of the damages caused in case of fire (e.g., $[2,17,18])$.

WUI has therefore become a central focus of the forest fire policy in Europe because wildfires occurring in these areas are not only affecting to forest but also to population, dwellings, industrial areas, communications networks, etc. In Spain, several studies have analyzed WUI with applications to a specific area (e.g. $[19,20])$, or to the whole country [17, 21]. Caballero et al. [17] presented a preliminary identification of WUI patterns in Spain, and their associated risk distribution by province. Herrero [21] mapped WUI for the entire country using the Corine Land Cover (CLC) to delimitate urban and forest areas. However, as this author recognized, the usage of CLC has several limitations associated with (i) its spatial resolution with a cartographic scale of 1:100,000, and (ii) the fact that the minimum mapping unit is of 25 ha and the minimum width of linear elements is $100 \mathrm{~m}$. This level of detail is therefore not enough for the study of WUI at a local spatial level, because all spatial entities with fewer dimensions (e.g. isolated houses, small group of houses) would be not correctly mapped. As a consequence of this, in certain areas of Spain, such as the region of Galicia, WUI areas are infra-valuated in this study [21]. In fact, given that Galician population is widely dispersed in the territory and that Galicia has one of the largest proportions of forest occupation in Spain, areas where human development features interact with wildland vegetation are common. Thus many small settlements and numerous isolated houses, alternating with cultivated areas, meadows and forest patches of scrub and woodland, characterize the landscape in this region. This highlights the importance of studying WUI as areas of great concern for firefighting [18].

In this paper we study the question of how the patterns of human settlements affect fire ignition risk by focusing in an area of Galicia with one of the highest incidence of forest fires during the studied period 1999-2008. Specifically, our 
objectives are the following: first, we aim to identify, classify and map the WUI areas combining cartographic information related to building configuration and fragmentation of forest vegetation. Second, we aim to determine which types of WUI are most affected by wildfires. Through spatial analysis, forest fire ignition points and areas of WUI are linked to determine if there is a significant relationship between the different types of WUI and the spatial patterns of wildfire ignitions points. The paper is organised as follows. In the second section, we present the study area, and introduce the database and the methodology applied. In the third section, we highlight the relation between wildfire occurrence and WUI categories in the studied area. The final section recapitulates the main points, and offers some conclusions.

\section{Materials and methods}

\subsection{Study area}

Galicia is located on the Northwest of Spain. Forests cover nearly $70 \%$ of its territory and approximately $67 \%$ of this forestland is wooded. Individual private ownership represents $68 \%$ of the forestland, while $30 \%$ is under collective private ownership (ownership is shared by a group of individuals living in the same community). There are more than 3,750 parishes dispersed across the territory. Our study is conducted in the county of Verín $\left(1,007.2 \mathrm{~km}^{2}\right)$, located in the South of Galicia (Figure 1) that includes 8 municipalities and 82 parishes. Average population is 29,019 inhabitants and population density is $29 \mathrm{inhab} / \mathrm{km}^{2}$.

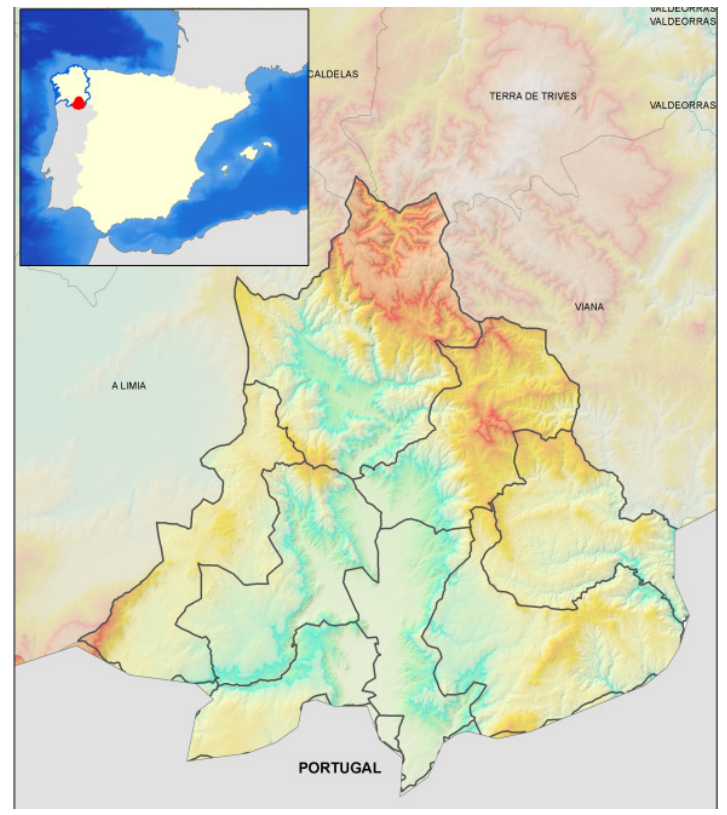

Figure 1: $\quad$ Study area. 
The major part of the territory corresponds with rural areas with the exception of the town of Verín, which accounts for about 30 percent of the total population.

\subsection{Data}

This study used data from two different cartographic covers as alternatives to the Corine Land Cover, employed by Herrero Corral [21], in order to obtain urban and forest information. We use a map of buildings from the National Topographic Base 1:25,000 (BTN25) which is elaborated by the National Geographic Institute (IGN). This map of buildings represents how urban settlements are scattered throughout the territory. This is combined with SIOSE (Information System on Land Cover in Spain) cartographic information, which is rasterized with a spatial resolution of $25 \mathrm{~m}$. and has a cartographic scale of $1: 25,000$. The SIOSE map provides detailed information about cover type distribution, because it has a minimum mapping unit of 2 ha for agrarian, forest, and natural areas, and a minimum width of linear elements of $15 \mathrm{~m}$. SIOSE does not classify a given polygon within a fixed hierarchical nomenclature but it allows assigning one or more covers to the same polygon, using shares of occupation. Moreover, it was refined and updated with the most recent aerial photo available (PNOA 2005-2008). Therefore, this source provides detailed and accurate information to better specify the complex landscape of Galicia with most of its territory occupied by mixed classes [22].

We also use a digitalized database of fire ignition points for the period 19992008 with a total of 85,784 wildland fires for the entire region, which burnt a total of 319,651 hectares over the studied time span. These data were obtained from the National Forest Fires Database (EGIF) compiled by the Rural Affairs Department of the Regional Government, and the Spanish Forest Service. Forest fire reports list general information regarding fires affecting, at least partially, forest and other wooded land areas. Data collected on these reports include area burned, date and estimated time of ignition, the geographic coordinates of its ignition point, causes and motivations, and fire-fighting measures applied. The ignition coordinates were evaluated and corrected when errors were detected. We refine the coordinates by using the administrative boundaries cartography (parishes, municipalities, population entities) at a scale of 1:25,000, a raster topographic map 1:25,000, and Landsat TM images. Finally, we discarded 329 ignition coordinates ( $9 \%$ of the total) because they cannot be correctly assigned to a specific spatial location. All the computations were made with ArcGIS 9.3.1 by ESRI and Geomedia Professional 6.0 by Intergraph.

\subsection{Methodology}

Following a similar approach to that adopted in Lampin-Maillet et al. [2] and Herrero Corral [21], we first classified buildings by habitat types using distance between buildings and buildings counting criteria. We distinguish four types of habitats: isolated, dispersed, dense clustered, and very dense clustered houses 
based on the number of buildings located in buffers of $50 \mathrm{~m}$ or $15 \mathrm{~m}$ of radius. In our case, isolated habitats refer to three or less building located less than 100 $\mathrm{m}$ apart. Dispersed habitats are those with a number of buildings between 4 and 50 that are located less than $100 \mathrm{~m}$ apart. Clustered habitats are those with more than 50 buildings located less than $100 \mathrm{~m}$ apart. In order to distinguish between the two different categories of clustered habitats (dense and very dense), we counted the number of buildings located less than $30 \mathrm{~m}$ apart (i.e., inside of a buffer of $15 \mathrm{~m}$ ). Dense habitat occurs when there are less than 8 buildings in the buffer and very dense habitat occurs when there are 8 or more buildings. When a building and its WUI delimitation were not classified belonging to just one type of these four habitat categories, a rule of predominance was established and the most clustered class took priority.

The map of buildings, 1:25,000 (BTN25), and the SIOSE land-cover map were used to select those human settlements that are in the zone of forest influence. This allows us to identify and map the WUI in the case study area. Estimation of the WUI is usually based on current legislation of forest fire prevention [21]. Galician statute (Law 3/2007 of April 9th of prevention and defense against forest fires) makes bush clearing obligatory within a $100 \mathrm{~m}$ perimeter around each house located at a distance of less than $400 \mathrm{~m}$ from forest or scrubland (art. 21). This distance is defined as the zone of forest influence. The combination of the WUI and habitat type layers allowed us to classify WUI using the categories presented above: isolated, dispersed, dense, and very dense.

The fragmentation of forest vegetation was classified using SIOSE cartographic information based on its horizontal continuity. The Landscape Fragmentation Tool (LFT v2.0) [23], run in $\operatorname{ArcGIS}^{\circledR}$ 9.3.1, was used in order to map the fragmentation present in the forest, distinguishing among core, patch, perforated, and edge, and non-forest. Under this tool, core forest consisted of any forest pixels that are more than 100 meters from non-forest (outside the edge effect) and thus are not degraded from proximity to other land cover types. Patch forest comprises coherent forest regions that are too small to contain core forest. Perforated forest defines the boundaries between core forest and relatively small perforations, and edge forest includes interior boundaries with relatively large perforations as well as the exterior boundaries of cores forest regions. In order to identify different levels of aggregation, we reclassified different types in just three classes of forest structure: high aggregation (core), low aggregation (patch, perforated, and edge forest), and non-forest. High aggregation means that vegetation is always present with a great level of continuity; while low aggregations indicates more open areas, sometimes adjacent to areas with no vegetation.

Finally, WUI and forest fragmentation layers were intersected and analyzed in order to obtain WUI by type of habitat and forest aggregation. This allows us to distinguish among 12 different WUI categories (Figure 2) and study also the spatial distribution of fire ignition points in order to characterize fire risk in these 12 categories. 


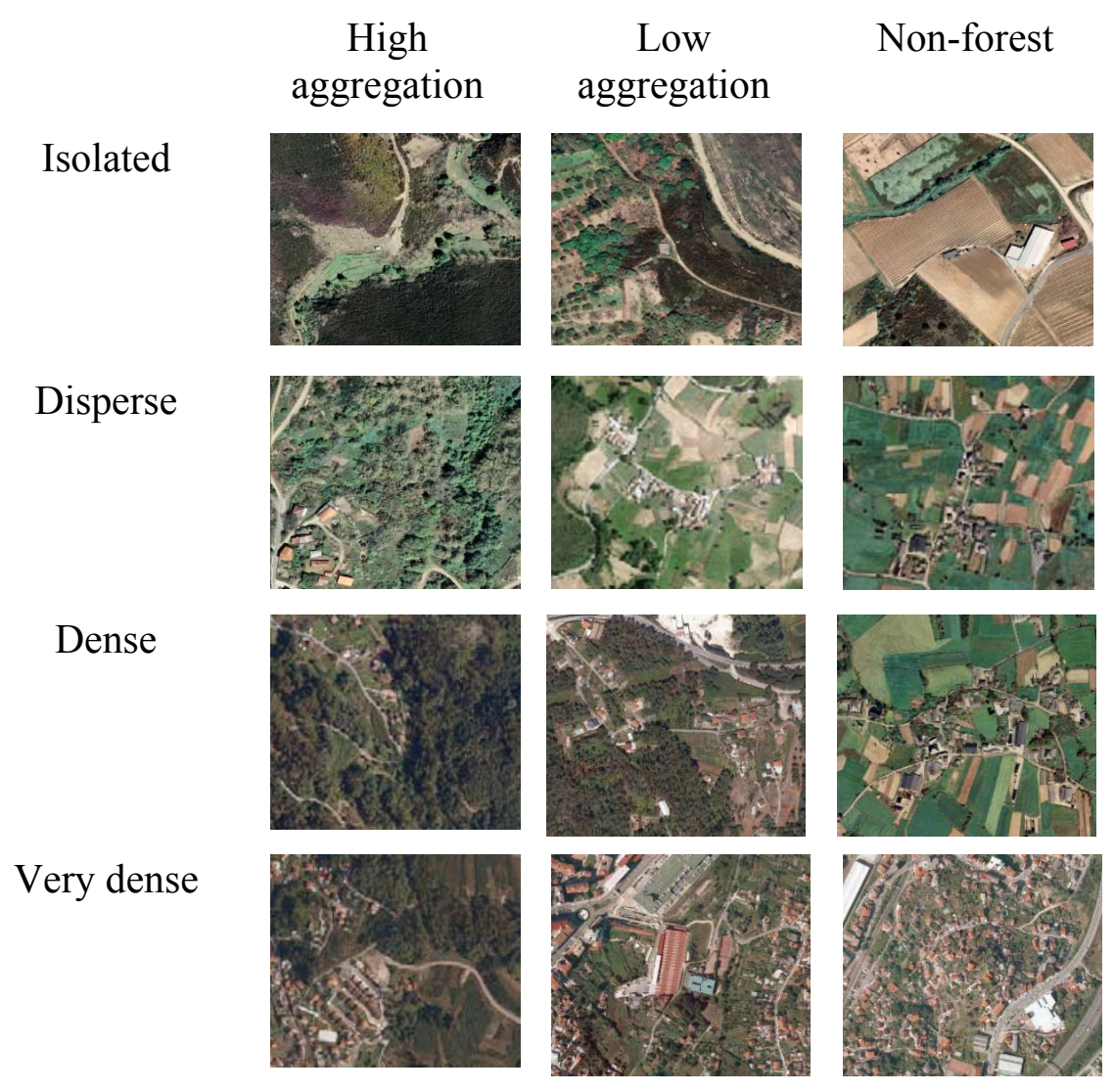

Figure 2: Wildland-urban interface typology.

\section{Results}

In the studied period, there were 3,682 forest fires affecting 23,966 ha. Nearly all, $94 \%$, of the fire ignitions in the county of Verín were classified as intentional; and $74 \%$ of those intentional fires are related to agricultural and shrubland burnings in rural areas. Fires caused by negligence and accidents only represented approximately $2 \%$ of the total ignitions, while those associated with unknown causes were $1 \%$, and natural-caused just $1.5 \%$. A $66 \%$ of the fires start in forest areas close to small roads, and gravel paths. In addition, more than half are ignited on weekdays, $22 \%$ on bank holidays, and $17 \%$ on Saturdays.

WUIs represented $9.3 \%$ of the study area. This percentage is significantly higher than that estimated by Herrero Corral [21] as the WUI for the whole region, around $0,7 \%$. This result seems to confirm that Galician WUI area was undervalued in Herrero Corral [21]. 
Table 1 shows the proportion of the different categories of WUI. In the county of Verín, WUI areas concentrate $98 \%$ of the total number of buildings. Based on information on building configuration, 26\% was isolated building, 20\% dispersed building, $29 \%$ dense clustering building and $35 \%$ very dense clustering building. Based on forest vegetation level of aggregation, more than half, $67 \%$ of WUI in our study is classified as non-forest areas. The remaining WUIs are evenly spread between areas with high and low level of forest vegetation aggregation.

Table 1: $\quad$ Main characteristics for WUI and non-WUI in the study area.

\begin{tabular}{|c|c|c|c|c|c|}
\hline & $\begin{array}{c}\text { Area } \\
\mathbf{( \% )}\end{array}$ & $\begin{array}{c}\text { Buildings } \\
\mathbf{( \% )}\end{array}$ & $\begin{array}{c}\text { Buildings/ } \\
\mathbf{k m}^{\mathbf{2}}\end{array}$ & $\begin{array}{c}\text { Ignition points } \\
\mathbf{( \% )}\end{array}$ & $\begin{array}{c}\text { Ignition } \\
\text { points/km }\end{array}$ \\
\hline WUI & 9.3 & 97.8 & 155.5 & 15.6 & 5.6 \\
\hline $\begin{array}{c}\text { WUI by } \\
\text { habitat types }\end{array}$ & & & & & \\
Isolated & 26.4 & 6.5 & 38.2 & 10.5 & 2.2 \\
Disperse & 20.2 & 18.9 & 144.7 & 25.2 & 6.9 \\
Dense & 28.8 & 9.1 & 75.2 & 9.4 & 2.8 \\
Very dense & 34.6 & 65.5 & 293.2 & 54.9 & 8.9 \\
\hline WUI by & & & & & \\
forest & & & & & \\
aggregation & 16.5 & 6.1 & 57.1 & 7.5 & 2.5 \\
Low & 16.5 & 4.4 & 41.1 & 1.1 & 0.4 \\
High & 67.0 & 89.5 & 207.3 & 91.4 & 7.6 \\
Non-forest & & & & & \\
\hline Non WUI & 90.7 & 2.2 & 0.4 & 84.4 & 3.1 \\
Low & 11.7 & 0.0 & 0.0 & 23.3 & 6.6 \\
High & 56.5 & 0.0 & 0.0 & 42.8 & 2.5 \\
Non-forest & 22.5 & 2.2 & 1.5 & 18.3 & 2.7 \\
\hline
\end{tabular}

The mean fire ignition density for the entire study area is 3.3 ignition points per $\mathrm{km}^{2}$. It is much higher in WUIs with 5.6 ignition points per $\mathrm{km}^{2}$, even though only $15.6 \%$ of the ignition points. Outside WUIs the density value is 3.1 fire ignition points per $\mathrm{km}^{2}$, but we found in this area $84 \%$ of fire ignitions. Thus, a $43 \%$ of the fires in the Verín county start in areas classified as non-WUI and characterized by with a high level of aggregation of forest vegetation (i.e. core forest). However, the highest ignition density occurs in non-WUI with low level of aggregation of forest vegetation (6.6 fire ignition points per $\mathrm{km}^{2}$ ). Notice that in neither of these areas there are any buildings.

Within WUIs, habitats with very dense clustered buildings present as expected the highest density of buildings per $\mathrm{km}^{2}$. Furthermore, they also show the highest density of fire ignition points per $\mathrm{km}^{2}$. At the same time, Table 1 also shows that within the WUIs, nearly all fires starts in non-forest areas (91\%), which implies a density value of 7.6 fire ignition points per $\mathrm{km}^{2}$. 
Fire ignition density was also calculated for the different 12 WUI types (Figures 2 and 3). The density values were significantly different for each type of WUI categories (chi-square $=522, \mathrm{df}=10, \mathrm{p}$-value $<0.001$ ). The WUI characterized by either dispersed housing or very dense clustered housing and non-forest vegetation areas, have the highest density value with 9.7 ignition points per $\mathrm{km}^{2}$. For the case of very dense clustered housing, the density value is also very high (7.6 ignitions points per $\mathrm{km}^{2}$ of WUI is 7.6) in those cases where there is also a low aggregation of forest vegetation. Non-forest areas combined with isolated building environments, and with dense clustered buildings have a fire density value of 4.1 and 3.9 ignitions per $\mathrm{km}^{2}$, respectively. There is a significant correlation between the density of buildings in $\mathrm{km} 2$ in WUI typologies and the density values of fire ignition points in those areas (Spearman $=0.8, p>0.05$ ).

\section{a) Area}

b) Buildings

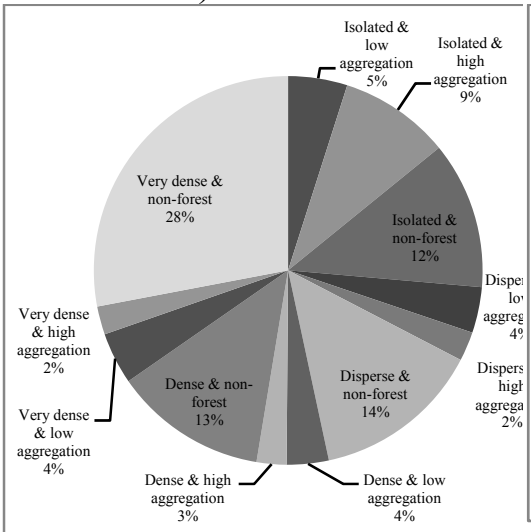

c) Ignition points in WUI

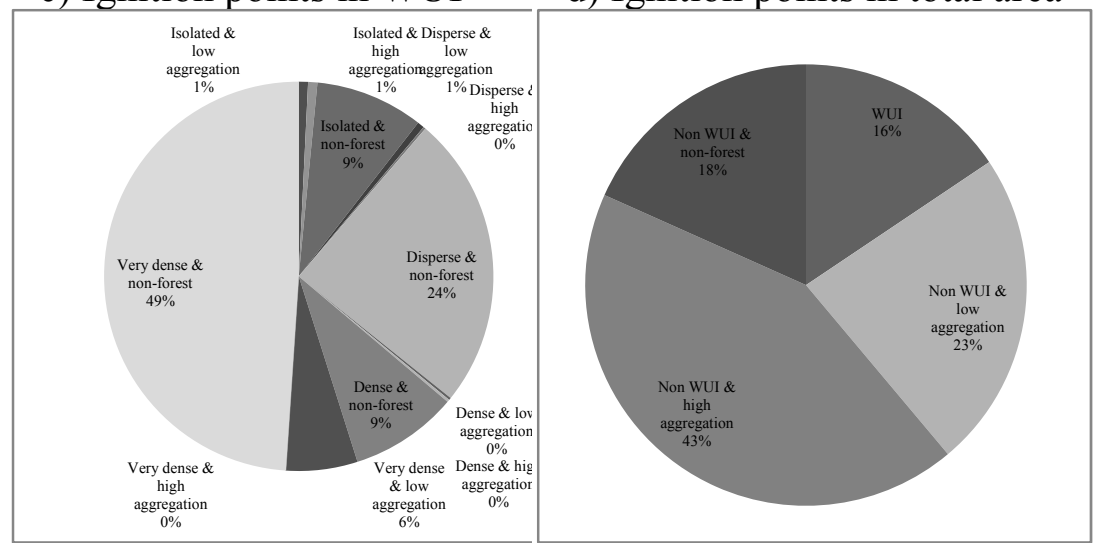

Figure 3: Distribution of a) area, b) buildings, c) ignition points by WUI typologies, and d) ignition points in total study area. 


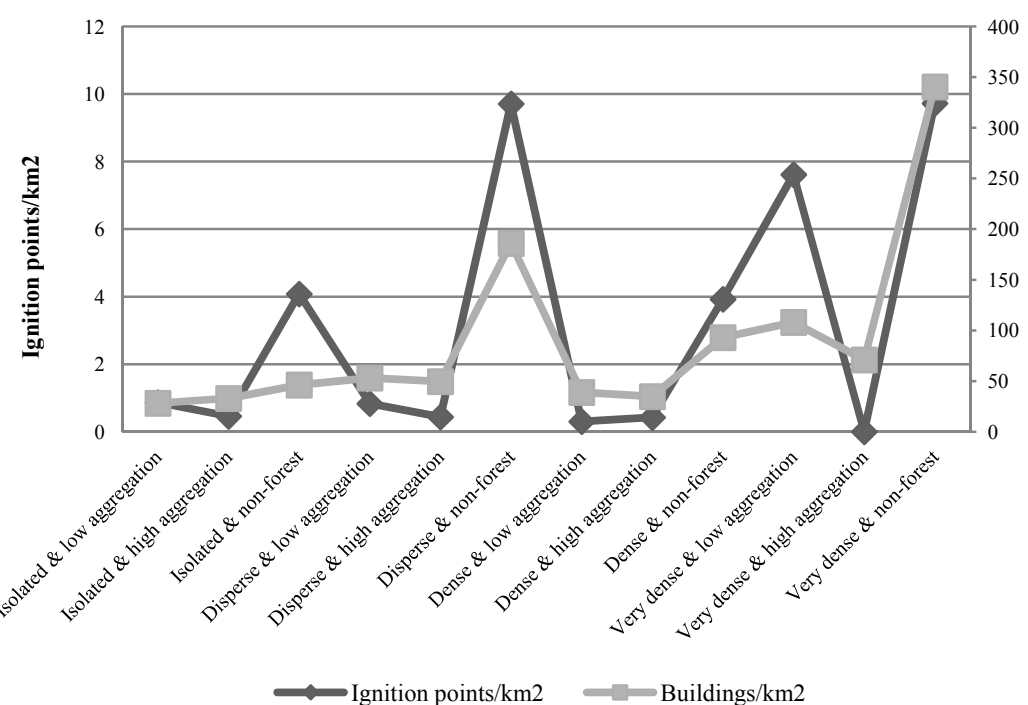

Figure 4: Number of ignition points and buildings per $\mathrm{km}^{2}$ in WUI typologies.

\section{Conclusions}

The analysis of the spatial distribution of fire ignition points shows a clear relationship with the wildland-urban interface. The results classified the WUI in twelve categories attending to four types of building configuration (isolated, dispersed, dense clustered and very dense clustered) and three types of levels of forest fragmentation (high and low level of aggregation of forest vegetation, and non-forest vegetation). Practically all of population settlements in the study area (98\% of houses/buildings) are located in the wildland-urban interface. This finding is consistent with the rural character of Verín county but it also highlights the vulnerability of this area, as fire is more likely to cause property damages, and therefore these areas require a special management against fire risk. In addition, the highest density of buildings occurs in WUIs that have either dispersed buildings or very dense clustered buildings and are also characterized by non-forest vegetation. These habitats also have the highest risk of forest ignitions, as most of the fires in the wildland-urban interfaces occur in these zones. They present thus the highest fire ignition density values with near 10 ignition points per $\mathrm{km}^{2}$. Fire risk is also high on habitats with very dense clustered buildings but with low aggregation of forest vegetation with near 8 ignitions per $\mathrm{km}^{2}$. This can be explained by the high proportion of intentional fires related to agricultural and shrubland burnings in this Galician county.

Defining WUI consistently and clearly is an important task, as different definitions of buildings configuration, forest aggregation structure or even area 
of forest influence can yield different results [24]. This work provides the basis to refine and improve WUI typology definitions with the objective of a future application to the whole region.

\section{Acknowledgements}

This research was funded by Consellería de Economía e Industria-Xunta de Galicia (Project 09SEC011201PR). The Spanish Forest Service and Consellería do Medio Rural (Xunta de Galicia) provide the forest fire database.

\section{References}

[1] Chas-Amil M.L., Touza J. \& Prestemon J.P., Spatial distribution of human-caused forest fires in Galicia (NW Spain). In G. Perona and C. A. Brebbia (eds.) Modelling, Monitoring and Management of Forest Fires. WIT Press. pp. 247-258, 2010.

[2] Lampin-Maillet, C., Jappiot, M., Long-Fournel, M., Bouillon, C., Morge, D. \& Ferrier, J.P., Mapping wildland-urban interfaces at large scales integrating housing density and vegetation aggregation for fire prevention in the South of France. Journal of Environmental Management 91, pp. 732-741, 2010.

[3] MARM (Ministerio de Medio Ambiente, medio rural y marino). Los incendios forestales en España 2009. 156 p, 2010.

[4] APAS (Asociación para la Promoción de Actividades Socioculturales) and IDEM (Instituto de Estudios del Medio). Estado del conocimiento sobre las causas de los incendios forestales en España. 50 p, 2006.

[5] Prestemon, J.P., Chas-Amil, M.L., Touza, J. \& Goodrick, S.J., Forecasting intentional wildfires using temporal and spatio-temporal autocorrelations. International Journal of Wildland Fire, Forthcoming.

[6] Narayanaraj, G. \& Wimberly M.C., Influences of forest roads on the spatial patterns of human- and lightning-caused wildfire ignitions. Applied Geography, 32, pp. 878-888, 2012.

[7] Padilla, M. \& Vega-Garcia, C., On the comparative importance of fire danger rating indices and their integration with spatial and temporal variables for predicting daily human-caused fire occurrences in Spain. International Journal of Wildland Fire, 20(1), pp. 46-58, 2011.

[8] Moreira, F., Viedma, O., Arianoutsou, M., Curt, T., Koutsias, N., Rigolot, E., Barbati, A., Corona, P., Vaz, P., Xanthopoulos, G., Mouillot, F. \& Bilgili, E. Landscape-wildfire interactions in southern Europe: implications for landscape management. Journal of Environmental Management (10), pp. 2389-402, 2011.

[9] Brosofske, K.D., Cleland, D.T. \& Saunders. S.C., Factors influencing modern wildfire occurrence in the Mark Twain National Forest, Missouri. Southern Journal of Applied Forestry, 31(2), pp. 73-84, 2007. 
[10] Maingi, J.K. \& Henry, M.C., Factors influencing wildfire occurrence and distribution in eastern Kentucky. International Journal of Wildland Fire, 16, pp. 23-33, 2007.

[11] Radeloff, V.C., Hammer, R.B., Stewart, S.I., Fried, J.S., Holcomb, S.S. \& McKeefry. J.F., The wildland-urban interface in the United States. Ecological Applications, 15(3), pp. 799-805, 2005.

[12] Syphard, A.D., Radeloff, V.C., Keeley, J.E., Hawbaker, T.J., Clayton, M.K., Stewart, S.I. \& Hammer. R.B., Human influence on California fire regimes. Ecological applications, 17(5), pp. 1388-1402, 2007.

[13] Syphard, A.D., Radeloff, V.C., Keuler N.S., Taylor, R.S., Hawbaker, T.J., Stewart, S.I. \& Clayton, M.K., Predicting spatial patterns of fire on a southern California landscape. International Journal of Wildland Fire, 17(5), pp. 602-613, 2008.

[14] Martínez, J., Vega-Garcia, C. \& Chuvieco, E., Human-caused wildfire risk rating for prevention planning in Spain. Journal of Environmental Management, 90, pp. 1241-1252, 2009.

[15] Vilar, L., Woolford, D.G., Martell, D.L. \& Martín M.P., A model for predicting human-caused wildfire occurrence in the region of Madrid, Spain. International Journal of Wildland Fire, 19, pp. 325-337, 2010.

[16] Badia A., Serra, P. \& Modugno, S., Indentifying dynamics of fire ignition probabilities in two representative Mediterranean wildland-urban interface areas. Applied Geography, 31, pp. 930-940, 2011.

[17] Caballero, D, Beltrán, I. \& Velasco A., Forest fires and wildland-urban interface in Spain: Types and risk distribution. 4th International Fire Conference. Seville, 13-17 May 2007.

[18] García González, J.M. \& Espinosa González, A., El peso creciente de los incendios en la interfaz urbano forestal. Análisis de los incendios forestales en Galicia acaecidos en agosto de $2006.4^{\text {th }}$ International Wildland Fire Conference. Seville, 14-17 May 2007.

[19] Galiana, L., Herrero, G. \& Solana. J., Caracterización y clasificación de interfaces urbano-forestales mediante análisis paisajístico. El ejemplo de Sierra Calderona (Comunidad Valenciana, España). $4^{\text {th }}$ International Wildland Fire Conference. Seville, 14-17 May 2007.

[20] Badia-Perpinyá, A., \& Pallarés. M., Spatial distribution of ignitions in Mediterranean periurban and rural areas: the case of Catalonia. International Journal of Wildland Fire, 15(2), pp. 187-196, 2006.

[21] Herrero Corral, G., Las interfaces urbano-forestales como territorios de riesgo frente a incendios: análisis y caracterización regional en España. $\mathrm{PhD}$ dissertation. Universidad Autónoma de Madrid, 2011.

[22] Díaz-Manso, J.M., Aller González, D., Martín Rosón, A., Barcia Noia, B., Paulo, S., Vega Fernández, J.A., Serantes, I., Fernández López, M. \& Loureiro Grandal. J., Two perspectives of land use and cover cartography in Galicia. XXII International Geographic Conference. A Coruña, 11-16 July 2005. 
188 Modelling, Monitoring and Management of Forest Fires III

[23] Vogt, P., Riitters, K.H., Estreguil, C., Kozak, J., Wade, T.G \& Wickham J. D., Mapping spatial patterns with morphological image processing. Landscape Ecology, 22, pp. 171-177, 2007.

[24] Platt, R.V., The wildland-urban interface: Evaluating the definition effect. Journal of Forestry, January-February, pp. 9-15, 2010. 